\title{
Correction to: The dopamine receptor D4 regulates the proliferation of pulmonary arteries smooth muscle in broilers by downregulating AT1R
}

Xiaoqi Yang ${ }^{1}$, Yang Fu', Lianfeng $\mathrm{Wu}^{1}$, Antong $\mathrm{Li}^{1}$, Luyao $\mathrm{Ji}^{1}$, Hao Li $\mathrm{i}^{1}$, Yuxuan Peng ${ }^{1}$, Jiabin Zhang ${ }^{1}$, Donghai Zhou ${ }^{1 *}$ and Huiping Zhou ${ }^{2^{*}}$

Correction to: Animal Diseases 1, 12 (2021)

https://doi.org/10.1186/s44149-021-00012-w

Following publication of the original article (Yang et al., 2021), the affiliation details for author affiliations 1 and 2 were incorrect.

The zip code for author affiliation 1 should be 430070, instead of CA 0070. The city and zip code for the author affiliation 2 should be Xianning 437100, instead of Wuhan 0070. In addition, the author affiliation 3 should be removed as it is same as the author affiliation 2 .

The author affiliations have been updated in this correction article and the original article (Yang et al., 2021) has been corrected.

Published online: 14 September 2021

\section{Reference}

Yang, et al. 2021. Animal Diseases 1: 12

\footnotetext{
The original article can be found online at https://doi.org/10.1186/s44149021-00012-w.

*Correspondence: bigdefoot@163.com; zhouhuiping0925@163.com

1Veterinary Clinical Medicine Laboratory, College of Veterinary Medicine, Huazhong Agricultural University, Shizishan Street, Wuhan 430070, People's Republic of China

${ }^{2}$ School of Basic Medical, Hubei University of Science \& Technology, Xianning 437100, People's Republic of China
}

(C) The Author(s). 2021 Open Access This article is licensed under a Creative Commons Attribution 4.0 International License, which permits use, sharing, adaptation, distribution and reproduction in any medium or format, as long as you give appropriate credit to the original author(s) and the source, provide a link to the Creative Commons licence, and indicate if changes were made. The images or other third party material in this article are included in the article's Creative Commons licence, unless indicated otherwise in a credit line to the material. If material is not included in the article's Creative Commons licence and your intended use is not permitted by statutory regulation or exceeds the permitted use, you will need to obtain permission directly from the copyright holder. To view a copy of this licence, visit http://creativecommons.org/licenses/by/4.0/. The Creative Commons Public Domain Dedication waiver (http://creativecommons.org/publicdomain/zero/1.0/) applies to the data made available in this article, unless otherwise stated in a credit line to the data. 